\title{
The Effect of Game Analytical Game (GAG) to Increase of Basic Skill Shooting Soccer Player 6-9 Years Old
}

\author{
Dede Dwiansyah Putra ${ }^{1, *}$, Moh Agung Setiabudi ${ }^{2}$, Usman Nasution $^{3}$, Ibrahim $^{3}$, Habibi Hadi Wijaya ${ }^{4}$, \\ Yafi Velyan Mahyudi ${ }^{5}$, Desy Tya Maya Ningrum ${ }^{5}$ \\ ${ }^{1}$ Department of Physical Education, Universitas PGRI Palembang, Indonesia \\ ${ }^{2}$ Department of Physical Education, Health and Recreation, Universitas PGRI Banyuwangi, Indonesia \\ ${ }^{3}$ Department of Physical Education, Health and Recreation, Universitas Negeri Medan, Indonesia \\ ${ }^{4}$ Department of Sports Science, Universitas Singaperbangsa Karawang, Indonesia \\ ${ }^{5}$ Independent Researcher, Indonesia
}

Received January 29, 2021; Revised April 8, 2021; Accepted April 30, 2021

\section{Cite This Paper in the following Citation Styles}

(a): [1] Dede Dwiansyah Putra, Moh Agung Setiabudi, Usman Nasution, Ibrahim, Habibi Hadi Wijaya, Yafi Velyan Mahyudi, "The Effect of Game Analytical Game (GAG) to Increase of Basic Skill Shooting Soccer Player 6-9 Years Old," International Journal of Human Movement and Sports Sciences, Vol. 9, No. 4, pp. 609 - 614, 2021. DOI: 10.13189/saj.2021.090401.

(b): Dede Dwiansyah Putra, Moh Agung Setiabudi, Usman Nasution, Ibrahim, Habibi Hadi Wijaya, Yafi Velyan Mahyudi (2021). The Effect of Game Analytical Game (GAG) to Increase of Basic Skill Shooting Soccer Player 6-9 Years Old. International Journal of Human Movement and Sports Sciences, 9(4), 609 - 614. DOI: 10.13189/saj.2021.090401.

Copyright $\odot 2021$ by authors, all rights reserved. Authors agree that this article remains permanently open access under the terms of the Creative Commons Attribution License 4.0 International License

\begin{abstract}
Training units are commonly used in basic techniques of playing football through training models for players over 12 years old. Drill practice is practiced more on players than games. The purpose of this study is to determine the effectiveness of the Game Analytical Game (GAG) training model in improving basic soccer shooting skills. This research method is quantitative research with Quasi-Experiment. The designs used were pre-test and post-test non-equivalent control group design. Participants who took part in this study were school soccer players (SSB) PORASS totaling 80 players aged 6-9 years. The data was collected by conducting tests using basic shooting technique instruments. The results of this study are based on data analysis through independent sample t-test. It is known that the sig (2-tailed) value is $0.000<0.05$ which indicates that the GAG model is effective in improving football shooting skills. It can be concluded that the GAG training model is effective in improving basic shooting technique skills in soccer games for SSB players aged 6-9 years. The literature that discusses the GAG training model in soccer games and studies investigating its effectiveness for improving the technique in players under 9 years old
\end{abstract}

are lacking. It is important for future research to examine whether the GAG training model is effective in improving basic skills of passing and control in football or other sports.

Keywords GAG Training Model, Shooting Basic Skill in Soccer

\section{Introduction}

That football is two opposing teams Marsico \& Cher (2013). Each team has the goal of getting the ball into the opponent's goal. Each team must defend the net from being conceded. The object of the games is to score more goals than the opponent Kelley (2008). It can be interpreted that the object of playing football is to create more goals against the opponent. Each goal is counted as one score, and the team that creates the most goals is declared the winner of the game (J. A. Luxbacher, 2001).

The game of football requires basic techniques. The 
basic techniques referred to in the soccer game are: (1) passing the ball, (2) dribbling, (3) shooting the ball into the goal (shooting), (4) ball control, (5) headings, (6) feinting, and (7) specific basic techniques for goalkeepers. With good mastery of basic technical skills, players will easily play football and achieve victory. Basic technical proficiency is an essential aspect of a football player's development (Serpiello, Cox, Oppici, Hopkins, \& Varley 2017).

The most crucial aspect that a football player has to master is the basic technique of kicking. The basic technique of kicking a ball is touching or pushing the ball using the feet. The primary purpose of kicking the ball is to pass the ball (pass), throw the ball away towards the opponents' defense, and shoot the ball towards the goal (shooting). Kicking is crucial in every match since its number and efficiency influence the final score (Izovska, Maly, Zahalka, et al., 2016).

One of the basic kicking techniques, which is characteristic and the most dominant activity for creating goals against opponents in soccer, is shooting because the main objective of every attack in a soccer game is to score a goal. A football player must master shooting skills and develop a series of shooting techniques (Izovska, Maly, \& Zahalka, 2016). Useful shooting techniques must be supported by strength, accuracy and right balance. The perfect shooting technique combines balance, control, accuracy, and power Mohammed \& Kohl (2016).

Good basic shooting technique skills make it possible to shoot goals from various positions on the field. To score, a football player must perform shooting skills under the pressure of the game, limited time, space-constrained, physically tired, and aggressive opponents (J. Luxbacher, 2011).

To acquire accurate and hard shooting skills is not an easy thing. Many factors influence the players' shooting to have good accuracy and strength. Shooting skills must be trained, and this is the final execution of the attack process. Shooting practice should start from the most straightforward sequences to the most complex ones. Suppose the players want to acquire good shooting skills, football players must be allowed to shoot as many goals as possible in shooting practice sessions. Players can improve their shooting skills in the match and make better use of shooting opportunities unless they practice more using different situations (Mielke, 2003).

The basic football technical skills outlined above are an essential part of playing football. Without good mastery of basic techniques, it will be difficult for players to run and win matches. It is essential to teach basic football techniques to players at a young age. Players have to become technically sound in soccer at a young age once a player learns a technique Koger (2005). It takes countless hours of practice through training drills for this technique to become a skill, which can use the technique to advantage during the conditions and restrictions of a game. Training players techniques should be done as early as possible so that players have a long time. In practicing a technique, it takes hours of practice for the technique to become a skill.

To improve the basic techniques of playing football, especially basic shooting techniques, what must be done is to guide with training stages following the needs of the age group, especially starting with the age of children. It is necessary to form through proper coaching starting from childhood, ranging from 6-9 years with an appropriate and systematic training process to produce a future of reliable football players.

In essence, the National Team of a country will not be strong without proper coaching starting with children aged 6-9 years. The development of these future players is an essential issue in the development of football from any country, like FIFA and AFC through grassroots programs that emphasize the importance of coaching issues, especially at the level of children in the joy phase.

In the author's quest to develop playing skills, football beginner has had to contend that $70 \%$ of the students decide to quit at the age of 12 . Because adults often forget that what they train are children, they also forget that children learn and act like children. Adults can play child's games, but children cannot always play adult games.

Based on these various explanations, the writer wants to realize a training model referring to the FIFA and AFC grassroots program, namely the Game Analytical Game training model, to improve basic shooting technique skills. The Game Analytical Game training model is a program whose main objective is to learn through games and teach children the basics of football to develop their own physical and mental capacities through play. The Game Analytical Game training model approach for players aged 6-9 years is a training model with the principle of learning through games.

Several studies also support the principle of learning through games. (Brueggemann, 2008) explains that the game is the best role model. Based on this philosophy, the essential demands of soccer are addressed. The first and most crucial demand requires players to practice what is needed and how it is needed. Besides, it is also supported by the Football Association of Singapore (FAS), which states in the Grassroots guide, FAS includes a large number of games, games selected for use in developing plans to make progress from fun games to playing football (Nordin, 2015).

The game approach lets kids discover what to do in the game by experiencing it (Johns, 2006). It means that the game approach allows children to discover what to do in play by directly experiencing it. All training sessions is essential, especially for players aged 6-9 years old, an exercise model that emphasizes fun (fun games) and contains learning. Training through a game process containing analytical learning can motivate children to understand and participate in the training. It can also improve children's playing skills, both in terms of 
techniques, tactics, and understanding (Emral, 2014).

Besides, based on the AFC Coaching Guide for Boys and Girls aged 6-12 years in coaching Grassroots states; (1) When involving children from 6-12 years of age, the emphasis on exercise and play programs should be fun and exciting supported by modified rules. (2) Training activities should focus on broad skills development without emphasis on specific skills or positions. (3) During the interaction with the children, the coach must provide a positive and joyful learning environment with recognition for their efforts, participation, skills improvement, social interaction, and good teamwork (Flath, 2006).

Also, play activities will bring children to experience better physiological changes. Someone who does play activities can have a happy, joyful, and more relaxed mood. By playing, someone can laugh and forget the pressure they experience due to their daily activities and learning. The Game Analytical Game model for children can provide fun entertainment and can increase the parameters of their physical capacity and playing skills (Christou, 2006).

The Game Analytical Game training model aims to improve learning that starts and ends with games (small-sided games) whose play area can be modified (Development, 2012). Supported this statement, which states a smaller playing area can improve passing performance (Oppici, Panchuk, Serpiello, \& Farrow, 2018).

Soccer games using small-sides games can stimulate technical, tactical, physical, and physiological components of performance in a context simulating a formal game (Elsangedy et al., 2016). Small-sided games can also simulate the workload and physiological intensity corresponding to the actual match while also developing technical and tactical proficiency (Wen et al., 2012).

The Game Analytical Game training model that the author applies refers to the Grassroot FIFA and AFC programs whose training sessions are as following table 1.

The training model through the GAG approach can be described in several phases. Game I is an introductory game that is modified to introduce the concept of playing real football to participants, emphasizing that students are getting much experienced with the ball and making decisions as quickly as possible. Then, it continues with analytical/skill development. It is a learning or repetition activity to improve the basic technical skills that are a problem in the first game. Moreover, it ends with (Game II), a game that resembles a modified match situation to provide students with the stimulus to implement these basic techniques in a game that resembles a match. The introduction of diamond-shaped formations is emphasized.

Throughout the researcher's experience, the model for training basic technical skills through the GAG is the most suitable method developed for players aged 9-12 years old to improve basic technical skills playing football. Several experts also supported this research, as stated by (Holt et al., 2006), with varied forms of training and adapting to various match situations. It is very suitable to improve students' playing skills. Learning through modified games in football is a useful tool for stimulating technical, tactical, physical, and physiological performance components in a context that simulates formal play (Elsangedy et al., 2016). Small-sided games can also simulate the workload and physiological intensity that corresponds to the actual match while also developing basic technical and tactical skills (Wen et al., 2012).

The advantage of the GAG training model is that technical, tactical, and physical aspects can be addressed holistically, making training more specific using the ball, increasing player motivation, and optimizing training time (Ided et al., 2012). Players will also be more directly involved in matches, as they are more in contact with the ball, make accurate passes, and shoot at goal more often.

It can be concluded that the use of the Game Analytical Game training model is a recommended training modality for significant improvement in performance and training efficiency through a combination of technical, tactical, and physical components. By supporting these skills during childhood, young soccer players may have a better chance of reaching elite performance levels later in their sporting careers (Forsman et al., 2016).

Table 1. Game Analytical Game Unit Training Table

\begin{tabular}{|c|c|c|c|c|}
\hline \multirow{3}{*}{ Warm-Up } & Game & Analytical & Game & \\
\cline { 2 - 5 } & Fun game & Adaptation & Match Format & Cooldown \\
& Game Related to Football & Engineering Exercises & Game 4 v 4 & Introduction to the \\
& Skill Development & Diamond Formation & \\
\hline
\end{tabular}




\section{Method}

The method used is Quasi-Experimental Design, where this design contains a control group that does not fully function to influence the implementation of the experiment. The research design was one group pre-test post-test design.

At this stage of the effectiveness test, eighty (80) players football (6-9 years old) were used as participants, with forty (40) participants in the experimental group and forty (40) participants in the control group. This operational trial was conducted for three months, starting with a pre-test and ending with a post-test. The experimental group was a group that used the GAG approach, while the control group continued to use the previous training model. Furthermore, to prove the significance of the difference in the effectiveness of the training model through the GAG approach with the traditional training model, it is necessary to test it statistically through several analysis stages, namely data normality t-test and independent-sample t-test.

\section{Results}

To see the effectiveness of the Analytical Game training model that needs to be done by football school participants who are divided into two groups, namely the experimental and control groups, the mean difference test (t-test) can be carried out. To analyze the data, a normality test (table 2 and 3 ) and a homogeneity test (table 4 and 5) of the data on the results of the study are previously carried out as a test requirement.

\section{Normality test}

Table 2. Tests of Normality of Experiment Group

\begin{tabular}{|c|c|c|c|c|c|c|}
\hline & \multicolumn{2}{|l}{ Kolmogorov-Smirnova } & \multicolumn{4}{c|}{ Shapiro-Wilk } \\
\hline & Statistics & $\mathrm{df}$ & Sig. & Statistics & $\mathrm{df}$ & Sig. \\
\hline $\begin{array}{c}\text { PreTest } \\
\text { shooting }\end{array}$ & .132 & 40 & .078 & .953 & 40 & .095 \\
\hline $\begin{array}{c}\text { PostTest } \\
\text { shooting }\end{array}$ & .131 & 40 & $.079 *$ & .930 & 40 & .016 \\
\hline
\end{tabular}

Based on the data table, the normality of experiment group shows the value of sig. in the Kolmogorov-Smirnov column for pre-test shooting data .078 , which means 0.078 post-test shooting is .079 , which means 0.079 . According to our test criteria, if the value is sig. more than 0.05 , then $\mathrm{H}_{0}$ is accepted. It means that the data is normally distributed.
Table 3. Table of Tests of Normality of Control Group

\begin{tabular}{|c|c|c|c|c|c|c|}
\hline & \multicolumn{3}{|c|}{ Kolmogorov-Smirnova } & \multicolumn{3}{c|}{ Shapiro-Wilk } \\
\hline & Statistics & df & Sig. & Statistics & df & Sig. \\
\hline $\begin{array}{c}\text { PreTest } \\
\text { shooting }\end{array}$ & .125 & 40 & .114 & .949 & 40 & .072 \\
\hline $\begin{array}{c}\text { PostTest } \\
\text { shooting }\end{array}$ & .108 & 40 & $.200 *$ & .970 & 40 & .356 \\
\hline
\end{tabular}

Based on the data table tests of normality of the control group, it can be seen the value of sig. in the Kolmogorov-Smirnov column for pre-test shooting data is .114, which means 0. 114, Post-test shooting is. 200, which means 0. 200. According to our test criteria, if the value is sig. more than 0.05 , then $\mathrm{H}_{0}$ is accepted. This means that the data is normally distributed.

\section{Homogeneity Test}

Table 4. Table Test of Homogeneity of Variance

\begin{tabular}{|c|c|c|c|c|c|}
\hline & & $\begin{array}{c}\text { Levene } \\
\text { Statistics }\end{array}$ & df1 & df2 & Sig. \\
\hline \multirow{3}{*}{$\begin{array}{c}\text { Shooting } \\
\text { practice } \\
\text { results }\end{array}$} & Based on Mean & .853 & 1 & 78 & .358 \\
\cline { 2 - 6 } & $\begin{array}{c}\text { Based on Median } \\
\text { and with adjusted df }\end{array}$ & .597 & 1 & 78 & .442 \\
\cline { 2 - 6 } & $\begin{array}{c}\text { Based on the } \\
\text { trimmed mean }\end{array}$ & .911 & 1 & 78 & .343 \\
\hline
\end{tabular}

Based on the SPSS output results, the significance based on the pre-test mean is $.358(0.358)>0.05$. It can be concluded that the experimental group shooting variance and the variant shooting of the control group are the same or homogeneous.

\section{Hypothesis Test (t-test)}

Table 5. Group Statistics table

\begin{tabular}{|c|c|c|c|c|c|}
\hline & Group & $\mathrm{N}$ & Mean & $\begin{array}{c}\text { Std. } \\
\text { Deviation }\end{array}$ & $\begin{array}{c}\text { Std. Mean } \\
\text { Error }\end{array}$ \\
\hline \multirow{2}{*}{ Shooting } & Experiment & 40 & 48.18 & 4,862 & .769 \\
\cline { 2 - 6 } & Control & 40 & 37.12 & 6,014 & .951 \\
\hline
\end{tabular}

The statistical group has 40 subjects. The post-test of the experimental group is higher than the control group, than the average is 48.18 to 37.12 . Therefore, the experimental group subjects are better than the control group. It can be concluded that the use of the basic GAG approach is effective in improving and improving basic shooting technique skills in school soccer (SSB) players aged 6-9 years old. 
Table 6. Independent Samples Test Table

\begin{tabular}{|c|c|c|c|c|c|c|c|c|c|c|}
\hline & & $\begin{array}{l}\text { Levene's Test } \\
\text { for Equality of }\end{array}$ & \multicolumn{8}{|c|}{ t-test for Equality of Means } \\
\hline & & \multirow[t]{2}{*}{$\mathrm{F}$} & \multirow[t]{2}{*}{ Sig. } & \multirow[t]{2}{*}{$\mathrm{t}$} & \multirow[t]{2}{*}{$\mathrm{df}$} & \multirow[t]{2}{*}{$\begin{array}{c}\text { Sig. } \\
\text { (2-tailed) }\end{array}$} & \multirow[t]{2}{*}{$\begin{array}{c}\text { Mean } \\
\text { Difference }\end{array}$} & \multirow{2}{*}{$\begin{array}{l}\text { Std. Error } \\
\text { Difference }\end{array}$} & \multicolumn{2}{|c|}{$\begin{array}{c}95 \% \text { Confidence Interval } \\
\text { of the Difference }\end{array}$} \\
\hline & & & & & & & & & Lower & Upper \\
\hline \multirow[b]{2}{*}{ Shooting } & $\begin{array}{c}\text { Equal } \\
\text { variances } \\
\text { assumed }\end{array}$ & .853 & .358 & 9,037 & 78 & .000 & 11,050 & 1,223 & 8,616 & 13,484 \\
\hline & $\begin{array}{c}\text { Equal } \\
\text { variances } \\
\text { not } \\
\text { assumed }\end{array}$ & & & 9,037 & 74,720 & .000 & 11,050 & 1,223 & 8,614 & 13,486 \\
\hline
\end{tabular}

From the independent sample table, it can be seen that the 2-way significance value (t-tailed) is $0.00<0.05$, so that there is a significant difference in point scores between the experimental group and the control group.

Based on the above conclusions, it can be said that there is a difference in the effectiveness of the GAG approach with the conventional training model in improving the basic shooting technique skills of school soccer SSB players aged 6-9 years old.

\section{Discussion}

Condition of research literature is related to Game Analytical Game training model. The research results showed that the level of effectiveness was significant, but this research was still limited to several universities. It is essential for all training sessions, especially for players aged 6-9 years, a training model that emphasizes fun, which contains learning. Through training that applies the basic techniques of effective soccer training it can improve the VO2max of young soccer players compared to conventional training (Bahtra et al., 2020). Through the coach's play activities, the learning approach can analyze skilled players and less skilled players (Romeas et al., 2016).

Coaches in formative stages should promote unequal game situations with superiority number of players in attack, to facilitate the decision-making and develop the technical skills thanks to a greater participation and a greater duration of ball possession (Práxedes et al., 2021). Apart from that, coaches can also improve their individual and tactical abilities through play (Gibson Moreira Praça, Filipe Manuel Clemente, André Gustavo Pereira de Andrade, Juan Carlos Perez Morales, 2017). 6-week basic-level strength yoga exercises had a positive effect on balance, flexibility, and strength in soccer players (Kartal \& Ergin, 2020).

The Game Analytical Game method has the principle of "learning the game of football through playing activities. The games approach lets kids discover what to do in the game not by telling them but by experiencing it (Johns, 2006)." The game is the best teacher (Brueggemann, 2008). Based on this philosophy, the essential demands of soccer are addressed. The first and most crucial demand requires players to practice what is needed and how it is needed. It means "the game is the best teacher". The essential basic demands of football require players to practice what they need and what is needed in the game.

\section{Conclusions}

The training model for basic football technical skills through the GAG approach can be carried out and effectively improves basic shooting technique skills in soccer school (SSB) players aged 6-9 years old. It is important for future research to test whether the GAG training model is effective in improving basic passing and control skills or in improving cooperation between players. In addition, it is also necessary to know whether the GAG model can lead to a soccer game situation.

\section{Acknowledgements}

Thanks to all respondents who are willing to be a sample in this study, so that this study can be completed as desired.

\section{REFERENCES}

[1] Anthony, S. (2011). The Australian College of Physical Education.

[2] Bahtra, R., Asmawi, M., Widiastuti, \& Dlis, F. (2020). Improved vo2max: The effectiveness of basic soccer training at a young age. International Journal of Human Movement and Sports Sciences, 8(3), 97-102. https://doi.org/10.13189/ saj.2020.080304

[3] Brueggemann, D. (2008). Soccer Alive. In The British Journal of Psychiatry (Vol. 111, Issue 479). https://doi.org/ 


\subsection{2/bjp.111.479.1009-a}

[4] Christou, M. (2006). Effects of R Esistance T Raining on the Soccer P Layers. Journal of Strength and Conditioning Research, 20(4), 783-791.

[5] Coker, CA (2004). Motor learning and Control Practitioners. Mexico: McGraw Hill.

[6] Development, C. (2012). Why BC Soccer is doing?

[7] Edward., WH (2010). Motor Learning and Control. USA: Wadsworth.

[8] Elsangedy, H. M., Hsin, C., Chao, N., \& Okano, A. H. (2016). Rev Bras Cineantropom Hum. April, 287-296.

[9] Emral. (2014). Pengembangan Grassoots di Kecamatan Batang Kapas Kabupaten Pesisir Selatan.

[10] Flath, T. (2006). AFC Coaching Guide for Boys and Girls aged 6-12 Tahun.

[11]Forsman, H., Blomqvist, M., \& Davids, K. (2016). Identifying technical, physiological, tactical and psychological characteristics that contribute to career progression in soccer. $0(0), 1-9$. https://doi.org/10.1177/174 7954116655051

[12] Gibson Moreira Praça, Filipe Manuel Clemente, André Gustavo Pereira de Andrade, Juan Carlos Perez Morales, and P. J. G. (2017). Network Analysis In Small-Sided And Conditioned Soccer Games: The Influence Of Additional Players And Playing Position. Kinesiology.

[13] Holt, J. E., Ward, P., \& Wallhead, T. L. (2006). The transfer of learning from play practices to game play in young adult soccer players. Physical Education \& Sport Pedagogy, 11(2), 101-118. https://doi.org/10.1080/17408980600708270

[14] Ided, S. M., Ames, S. O. G., Brantes, C. A. I. A., Unes, M. A. I. N., \& Ac, V. I. M. M. (2012). E Ffects of the N Umber of $P$ Layers and G Ame. 27(19), 976-981.

[15] Izovska, J., Maly, T., \& Zahalka, F. (2016). Relationship between speed and accuracy of instep soccer kick. Journal of Physical Education and Sport, 16(2), 459-464. https://doi.org/10.7752/jpes.2016.02070

[16] Izovska, J., Maly, T., Zahalka, F., Izovska, J., Maly, T., \& Zahalka, F. (2016). Relationship between speed and accuracy of instep soccer kick. 16(2), 459-464. https://doi.org/10.7752/jpes.2016.02070

[17] Johns, R. C. (2006). Coaching youth soccer. Human Kinetic.

[18] Jhon, SW (2011). Child Development Period. Jakarta: Humanika.

[19] Judith E. Rink. (2010). Teaching Physical Education for Learning, 6th Edition. New York: McGraw-Hill Co., Inc.

[20] Kartal, A., \& Ergin, E. (2020). Investigation of the effect of 6-week Yoga exercises on balance, flexibility, and strength in soccer players. International Journal of Human Movement and Sports Sciences, 8(3), 91-96. https://doi.org/10.13189/s aj.2020.080303

[21] Kelley, K. C. (2008). Soccer. In The British Journal of
Psychiatry (Vol. 112, Issue 483). United States of America by Cherry Lake Publishing. https://doi.org/10.1192/bjp.112. 483.211-a

[22] Luxbacher, J. (2011). Sepakbola. PT Rajagrafindo Persada.

[23] Luxbacher, J. A. (2001). Sepakbola. PT Raja Grafindo.

[24] Marsico, C. M. and K., \& Cher. (2013). Real World Match Soccer. In Journal of Chemical Information and Modeling (Vol. 53, Issue 9). United States of America by Cherry Lake Publishing. https://doi.org/10.1017/CBO9781107415324.004

[25] Mazzantini, Mirko and Bombardieri, S. (2013a). Full Season Academy Training Program "48 Sessions (245 Practices) from Italian Serie 'A' Coaches.

[26] Mielke, D. (2003). Seri Dasar-dasar Olahraga: Dasar-dasar Sepakbola. Pakar Raya.

[27] Mohammed, Z., \& Kohl, K. (2016). Which Orthoptic Visual Approach Evaluates Shooting Skill Accuracy in Soccer Players? JPES ${ }^{\circledR}$. Journal of Physical Education and Sport $\AA$, 16 (2), 471-475. https://doi.org/10.7752/jpes.2016.02072

[28] Nordin, Z. (2015). Grassroots Manual for Age 6 to 9 Football Association Of Singapore.

[29] Owen, Adam. (2016). Football Conditioning a Modern Scientific Approach "Fitness Training, Speed \& Agility, Injury Prevention Title. soccertutor.

[30] Práxedes, A., Pizarro, D., Travassos, B., Domínguez, M., \& Moreno, A. (2021). Level of opposition constrains offensive performance in consecutive game situations. An analysis according to game principles. Physical Education and Sport Pedagogy. https://doi.org/10.1080/17408989.2021.1877269

[31] Richard A. Schmidt, CAW (2000). Motor Learning and Performance, 2nd Edition. United States: Human Kinetic.

[32] Romeas, T., Guldner, A., \& Faubert, J. (2016). 3D-Multiple Object Tracking training task improves passing decision-making accuracy in soccer players. Psychology of Sport and Exercise, 22, 1-9. https://doi.org/10.1016/j.psych sport.2015.06.002

[33] Schmidt and Wrisberg N. (2000). motor learning and performance. USA: Human Kinetic.

[34] Serpiello, F. R., Cox, A., Oppici, L., Hopkins, W. G., \& Varley, M. C. (2017). The Loughborough Soccer Passing Test has impractical criterion validity in elite youth football. Science and Medicine in Football, 1(1), 60-64. https://doi.org/10.1080/02640414.2016.1254810

[35] Thomas, C., Fellingham, G., \& Vehrs, P. (2009). Development of a notational analysis system for selected soccer skills of a women's college team. Measurement in Physical Education and Exercise Science, 13 (2), 108121.https://doi.org/10.1080/10913670902812770

[36] Wen, A. D. A. M. L. O., Ong, D. E. L. P. W., Aul, D. A. P., \& Ellal, A. L. D. (2012). Effects of A Periodized Small-Sided Game Training Intervention On Physical Performance In Elite Professional Soccer. 2748-2754. 